\title{
Pembelajaran Fisika dengan Metode Eksperimen untuk Meningkatkan Hasil Belajar Kognitif dan Keterampilan Proses Sains
}

\author{
Yuliana Subekti $^{1}$, A. Ariswan ${ }^{2}$ \\ ${ }^{12}$ Program Studi Pendidikan Sains, Program Pascasarjana, Universitas Negeri Yogyakarta. Jalan \\ Colombo No. 1, Karangmalang, Yogyakarta, 55281, Indonesia \\ * Korespondensi Penulis. Email: sihkusuma@ gmail.com, Telp: +62274-550836
}

\begin{abstract}
Abstrak
Penelitian ini bertujuan untuk mengetahui ada tidaknya peningkatan hasil belajar aspek kognitif dan keterampilan proses sains ditinjau dari kemampuan awal fisika siswa dengan model pembelajaran inkuiri terbimbing melalui metode eksperimen. Jenis penelitian ini adalah penelitian quasi eksperimen. Populasi penelitian ini adalah seluruh siswa kelas X di SMA Negeri 9 Yogyakarta pada semester genap tahun ajaran 2014/2015 yaitu 192 siswa. Sampel dipilih sebanyak dua kelas dengan menggunakan teknik cluster randomized sampling yaitu 64 siswa. Aspek keterampilan proses sains yang diteliti yaitu pengamatan, pelaksanaan penelitian, pengkomunikasian, peramalan dan penyimpulan. Teknik analisis data yang digunakan adalah uji MANCOVA dengan taraf signifikansi 0,05. Hasil penelitian ini menunjukkan bahwa terdapat peningkatan yang signifikan hasil belajar fisika aspek kognitif dan keterampilan proses sains ditinjau dari kemampuan awal fisika pada siswa kelas X di SMA Negeri 9 Yogyakarta dengan model pembelajaran inkuiri terbimbing melalui metode eksperimen.
\end{abstract}

Kata Kunci: model pembelajaran inkuiri terbimbing, metode eksperimen, keterampilan proses sains, hasil belajar aspek kognitif.

\section{The Physics Learning with Experimental Methods to Increase Cognitive Aspects of Learning Outcomes and Science Process Skills}

\begin{abstract}
This study aims to investigate whether there is an increase of the cognitive aspects of learning outcomes and science process skills in terms of the first physics ablility with guided inquiry learning model through the experimental method. This type of research is quasi experimental research. The study population was all students of class X in SMA $N 9$ Yogyakarta in the second semester of 2014/2015 academic year as many as 192 students. The samples were as many as two classes using cluster randomized sampling technique were 64 students. The aspects of the science process skills were constructing observations, conducting research, communicating, predicting and making inferences. The data were analyzed using MANCOVA with the significance level of 0.05. The results of the study show that there is a significant increase of the cognitive aspect of physics learning outcomes and science process skills in terms of the firts physics ability of the class $X$ students in SMA $N 9$ Yogyakarta with guided inquiry learning model through the experimental methods.
\end{abstract}

Keywords: guided inquiry learning model, experimental method, science process skills, cognitive aspects of learning outcomes

How to Cite: Subekti, Y., \& Ariswan, A. (2016). Pembelajaran fisika dengan metode eksperimen untuk meningkatkan hasil belajar kognitif dan keterampilan proses sains. Jurnal Inovasi Pendidikan IPA, 2(2), 252261. doi:http://dx.doi.org/10.21831/jipi.v2i2.6278

Permalink/DOI: http://dx.doi.org/10.21831/jipi.v2i2.6278 


\section{PENDAHULUAN}

Undang-undang Sistem Pendidikan Nasional Nomor 20 Tahun 2003 menyatakan bahwa tujuan pendidikan nasional adalah mencerdaskan kehidupan bangsa dan mengembangkan manusia Indonesia seutuhnya yaitu manusia yang bertaqwa kepada Tuhan Yang Maha Esa dan berbudi pekerti luhur, memiliki pengetahuan dan keterampilan, kesehatan jasmani dan rohani, kepribadian yang mantap dan mandiri serta tanggungjawab kemasyarakatan dan kebangsaan.

Untuk meningkatkan kualitas pendidikan di Indonesia salah satu caranya adalah dengan melaksanakan proses belajar dan pembelajaran yang efektif sehingga hasil belajar dapat dicapai dengan optimal. Belajar merupakan salah satu faktor yang berperan untuk memberikan pengaruh dalam proses pembentukan pribadi dan perilaku seorang individu. Sebagian perkembangan individu berlangsung melalui kegiatan belajar secara komprehensif dan berkelanjutan. Setelah melakukan pembelajaran siswa akan mendapatkan hasil belajar.

Dalam menilai hasil belajar harus dalam tiga ranah yaitu ranah kognitif, ranah afektif dan ranah psikomotorik. Ranah kognitif terdiri dari enam jenis perilaku yaitu pengetahuan, pemahaman, penerapan, analisis, sintesis dan evaluasi. Ranah afektif terdiri dari lima perilaku yaitu penerimaan, partisipasi, penilaian dan penentuan sikap, organisasi serta pembentukan pola hidup. Ranah psikomotorik terdiri dari tujuh jenis perilaku yaitu persepsi, kesiapan, gerakan terbimbing, gerakan yang terbiasa, gerakan kompleks, penyesuaian pola gerakan dan kreativitas (Bloom et al, 1956, p.7).

Pada kenyataannya, dalam menilai hasil belajar sering ditafsirkan hanya dengan penilaian ranah kognitif saja. Penilaian yang terfokus pada produk (kognitif) mengakibatkan peserta didik mengabaikan sikap dan proses imliah karena untuk mengerjakan soal peserta didik cukup dengan menghafal rumus-rumus saja. Instrumen penilaian dengan tes formal, banyak digunakan selama ini dan cukup efektif digunakan pada penilaian aspek kognitif. Namun tes ini dianggap belum mampu mengukur kemampuan yang sebenarnya karena baru pada aspek produk saja dan belum mencakup aspek-aspek lain seperti aspek keterampilan proses sains. Hal ini disebabkan tes hanya sering memperkuat kemampuan menghafal daripada memahami (Brandsford et al, 1999, p.24).
Undang-undang Nomor 20 Tahun 2003 tentang Sistem Pendidikan Nasional juga menyebutkan bahwa pendidikan nasional harus mampu menjamin pemerataan kesempatan pendidikan, peningkatan mutu dan relevansi serta efisiensi manajemen pendidikan. Peningkatan mutu pendidikan diarahkan untuk meningkatkan kualitas manusia Indonesia seutuhnya melalui olahhati, olahpikir, olahrasa dan olahraga agar memiliki daya saing dalam menghadapi tantangan global.

Pada kenyataannya mutu pendidikan di Indonesia masih tergolong rendah khususnya pada pembelajaran sains. Hal ini dapat dilihat dari Trends in International Mathematics and Science Study (TIMSS) tahun 2007 dalam Martin et.al (2008, p.452) literasi sains khususnya fisika, Indonesia berada di urutan ke 36 dari 49 negara dengan pencapaian skor 432 , dan masih di bawah skor rata-rata internasional yaitu 500. Bahkan menurut Kompas yang terbit pada tanggal 5 Desember 2013, literasi sains dalam OECD tahun 2012 Indonesia berada pada urutan 64 dari 65 negara yang berpartisipasi.

Hasil belajar sains khususnya fisika yang rendah semakin jelas terlihat ketika mencermati hasil ulangan, ujian akhir semester bahkan hasil ujian akhir sekolah. Hampir dalam setiap ujian akhir sekolah, mata pelajaran fisika cenderung menempati posisi nilai terendah jika dibandingkan dengan nilai mata pelajaran yang juga diujikan. Penelitian yang dilakukan oleh Asminah (2010, p.3) menunjukkan bahwa nilai fisika ratarata yang diperoleh siswa pada ujian akhir semester genap di salah satu SMA di Surakarta adalah 63,5. Ini memperlihatkan bahwa pembelajaran fisika dikatakan kurang berhasil karena belum mencapai kriteria ketuntasan minimal yang ditentukan sekolah yaitu 65. Dalam hasil penelitiannya juga disebutkan bahwa masih banyak siswa yang tidak tuntas dengan nilai dibawah KKM sehingga harus mengikuti remidiasi.

Rendahnya mutu pendidikan di Indonesia, khususnya pembelajaran sains salah satu penyebabnya adalah pembelajaran sains tidak diajarkan sesuai dengan karakteristik sains itu sendiri. Asminah (2010, p.3) menyatakan salah satu faktor kurang berhasilnya pembelajaran adalah guru dalam memilih metode pembelajaran tidak sesuai dengan mata pelajaran fisika, guru kurang mengaktifkan siswa sehingga siswa hanya sebagai pendengar saja sehingga berakibat kreativitas siswa terabaikan. 
Fisika dikelompokkan sebagai pengetahuan fisis. Oleh karena fisika adalah pengetahuan fisis, maka sangat jelas bahwa untuk mempelajari fisika dan membentuk pengetahuan tentang fisika, diperlukan kontak langsung dengan hal yang ingin diketahui. Inilah sebabnya dalam fisika terdapat metode eksperimen dan inkuiri, dimana siswa dapat mengamati, mengukur, mengumpulkan data, menganalisa data, dan menyimpulkan sangat cocok dalam mempelajari fisika (Suparno, 2007, p.12).

Berdasarkan uraian tersebut dapat disimpulkan bahwa fisika adalah pengetahuan yang mempelajari kejadian-kejadian yang bersifat fisis yang mencakup proses, produk dan sikap ilmiah yang bersifat siklik, saling berhubungan, dan menerangkan bagaimana gejala-gejala alam tersebut terukur melalui pengamatan dan penelitian. Produk dalam hal ini merupakan kumpulan pengetahuan yang dapat berupa fakta, konsep, prinsip, hukum, dan teori. Proses merupakan langkah-langkah yang harus ditempuh untuk memperoleh pengetahuan misalnya mengamati, menafsirkan pengamatan, mengklarifikasi, meramalkan, menerapkan konsep, merencanakan percobaan, berkomunikasi dan menyimpulkan. Sikap ilmiah terbentuk saat melakukan proses, misalnya objektif dan jujur pada saat mengumpulkan dan menganalisa data (Mariana \& Praginda, 2009, pp.23-24).

Pembelajaran sains khususnya fisika harus diajarkan sesuai dengan karakteristik fisika melalui pengukuran langsung, penggunaan metode eksperimen, demonstrasi dan penjabaran rumus. Mata pelajaran fisika di SMA dikembangkan untuk mendidik siswa agar mampu mengembangkan observasi dan eksperimentasi serta berpikir taat asas. Berpikir taat asas dikembangkan dari kemampuan matematis yang dimiliki lewat pelajaran matematika. Kemampuan observasi dan eksperimentasi ditekankan pada melatih kemampuan berpikir eksperimental. Kemampuan berpikir eksperimental mencakup tata laksana eksperimen dan mengenal peralatan laboratorium.

Materi fisika untuk SMA kelas X salah satunya adalah suhu dan kalor dengan standar kompetensi 4. yaitu menerapkan konsep kalor dan prinsip konservasi energi pada berbagai perubahan energi. Karakteristik materi suhu dan kalor merupakan materi pelajaran yang bisa diamati oleh siswa secara langsung. Pada materi suhu dan kalor banyak berkaitan dengan kehidupan sehari-hari sehingga materi suhu dan kalor penting untuk dipahami oleh siswa. Akan tetapi banyak siswa yang belum dapat menghubungkan materi yang diajarkan dengan kehidupan sehari-hari. Hal ini dikarenakan pembelajaran IPA yang diselenggarakan kurang sesuai dengan karakteristik dan hakikat IPA sehingga mengakibatkan materi IPA fisika menurut siswa terlalu banyak rumus yang harus dihafalkan, kurang bisa menangkap hubungan materi yang diajarkan dengan kehidupan sehari-hari dan materi fisika kurang bermakna bagi siswa (Prakosa, 2011, p.4).

Dalam pembelajaran suhu dan kalor kurang berhasil bila tidak ditunjang dengan kegiatan eksperimen. Prakosa (2011, p.7) juga menyatakan bahwa fisika merupakan bagian dari sains, sehingga apa yang ditekankan dalam pembelajaran sains juga berlaku pada pembelajaran fisika. Dengan demikian pembelajaran fisika seyogyanya juga diarahkan pada pembelajaran penemuan (inquiry). Oleh sebab itu, dibutuhkan suatu model pembelajaran yang dapat menunjang kegiatan eksperimen yang salah satunya adalah model pembelajaran inkuiri terbimbing dengan metode eksperimen.

Setelah melakukan observasi di SMA Negeri 9 Yogyakarta dan memperhatikan hasil penelitian yang dilakukan sebelumnya dapat dikatakan bahwa pembelajaran fisika yang digunakan di SMA masih menggunakan model pembelajaran konvensional. Hal ini dibuktikan dengan pembelajaran yang masih berpusat pada guru dan masih dominannya pembelajaran dengan menggunakan metode ceramah. Oleh karena itu, pengembangan aspek keterampilan proses sains terutama melalui percobaan/ eksperimen belum maksimal. Kadang siswa mengikuti pembelajaran fisika dengan melakukan eksperimen namun masih berpusat pada guru sehingga kurang maksimal. Soal-soal yang dikembangkan dalam mengukur kemampuan fisika juga masih berkisar pada kemampuan menghafal konsep dan rumus. Oleh sebab itu, sebaiknya siswa diberikan pembelajaran fisika dengan pembelajaran proses dimana melibatkan siswa secara aktif dalam pembelajaran dengan melakukan pengamatan dalam memperoleh pengetahuan/konsep pembelajaran sehingga pembelajaran bermakna. Pembelajaran bermakna diharapkan mampu bertahan lama di ingatan/memori siswa karena siswa menemukan pengetahuannya melalui metode ilmiah sehingga hasil belajar siswa diharapkan juga dapat terjadi peningkatan. Metode ilmiah adalah metode yang sangat jelas untuk menunjukkan proses abstraksi 
terhadap kejadian konkrit,dan metode ini tepat untuk mempelajari fisika (Suparno, 2007, p.12).

Berdasarkan latar belakang masalah di atas, maka tujuan penelitian ini dilakukan adalah untuk mengetahui ada tidaknya peningkatan hasil belajar aspek kognitif dan keterampilan proses sains ditinjau dari kemampuan awal fisika pada siswa kelas X di SMA Negeri 9 Yogyakarta dengan menggunakan model pembelajaran inkuiri terbimbing melalui metode eksperimen.

Menurut Joyce dan Weil (2003, p.7) model pembelajaran merupakan suatu perencanaan atau suatu pola yang digunakan sebagai pedoman dalam merancang pembelajaran di kelas atau pembelajaran dalam tutorial dan untuk menentukan perangkat-perangkat pembelajaran. Model pembelajaran dapat diartikan pula sebagai kerangka konseptual yang digunakan sebagai pedoman dalam melakukan suatu kegiatan untuk mendukung proses belajar mengajar. Terdapat beberapa model pembelajaran, salah satunya adalah model pembelajaran inkuiri.

Inkuiri merupakan suatu proses pemaparan informasi, memperlihatkan hasil, observasi yang cermat, analisis dan bahkan inkuiri juga dapat menolak teori yang bertentangan dengan hasil pengalaman yang dialami secara langsung dari observasi (Tavalin, 2002, p.13). Inkuiri juga didefinisikan sebagai proses untuk mendiagnosa masalah, mengkritisi percobaan, suatu alternatif dalam membedakan, investigasi perencanaan, meneliti dugaan, mencari informasi, membangun model, berdebat dengan teman sebaya dan membentuk argumen yang koheren (Vlassi dan Karaliota, 2013, p.1). Inkuiri sebagai cara untuk mempelajari masalah ilmiah dalam konteks kehidupan nyata (McBride et al, 2004, p.1).

Model pembelajaran inkuiri tidak hanya mengembangkan kemampuan intelektual tetapi seluruh potensi yang ada, termasuk berpikir kritis dan mampu memecahkan masalah (Dimyati dan Mudjiono, 1999, p.173). Model pembelajaran ini secara umum menekankan suatu pertanyaan dan gagasan yang mendorong siswa untuk lebih belajar dan kreatif dalam menyampaikan pengetahuan mereka (Kuhlthau et al, 2007, p.2). Model pembelajaran inkuiri membimbing siswa dalam menggunakan pendekatan analitis yang mencakup semua tahapan dalam proses penyelidikan. Selain itu dalam model pembelajaran inkuiri terdapat konten dan instruksi yang terstruktur yang dapat digunakan untuk menguraikan keterampilan dan strategi yang dibutuhkan dalam setiap tahapan proses penyelidikan (Alberta Education, 2004, p.8).
Model pembelajaran ini juga merupakan salah satu model pembelajaran yang cocok untuk membantu siswa dalam mempelajari suatu konsep makroskopik maupun mikroskopik (Villagonzalo, 2014, p.2). Model pembelajaran inkuiri terbagi menjadi dua jenis berdasarkan besarnya intervensi guru terhadap siswa atau besarnya bimbingan yang diberikan oleh guru kepada siswanya yang salah satunya adalah model pembelajaran inkuiri terbimbing.

Model pembelajaran inkuiri terbimbing adalah model pembelajaran inkuiri dengan bimbingan dari guru (Kuhlthau et al, 2007, p.1). Misalnya dalam penyampaian pelajaran dengan penelaahan sesuatu yang bersifat pencarian secara kritis, analitis, dan argumentative secara ilmiah dengan menggunakan langkah-langkah tertentu menuju suatu kesimpulan. Guru memberikan bimbingan atau petunjuk yang jelas kepada siswa. Langkah-langkah yang dimaksud adalah orientasi, perumusan masalah, perumusan hipotesis, siswa mencari informasi, data, fakta yang diperlukan, menguji hipotesis, dan menarik kesimpulan jawaban (Mulyasa, 2011, p.109).

Jadi dapat dikatakan bahwa model pembelajaran inkuiri terbimbing yaitu suatu model pembelajaran inkuiri yang dalam pelaksanaannya guru menyediakan bimbingan atau petunjuk cukup luas kepada siswa. Sebagian perencanaannya dibuat oleh guru, siswa tidak merumuskan problem atau masalah. Guru memberikan arahan dan merumuskan masalah sedangkan siswa melakukan kegiatan untuk menyelidikinya (Ozdilek dan Bulunuz, 2009, p.26).

Model pembelajaran inkuiri terbimbing biasanya digunakan terutama bagi siswa yang belum berpengalaman belajar dengan pendekatan inkuiri, misalnya dalam transisi dari pengalaman belajar dengan menggunakan metode ceramah (Jack, 2013, p.11). Pada tahap-tahap awal pengajaran diberikan bimbingan lebih banyak seperti pernyataan dan pertanyaan pengarah yang selain dikemukakan langsung oleh guru juga diberikan melalui pertanyaan yang terdapat dalam Lembar Kerja Siswa (LKS). Hal ini dimaksudkan agar siswa mampu menemukan sendiri arah dan tindakan-tindakan yang harus dilakukan untuk memecahkan permasalahan yang disodorkan oleh guru. Oleh sebab itu lembar kerja siswa (LKS) dibuat untuk membimbing siswa dalam melakukan eksperimen dan menarik kesimpulan. Pertanyaan yang terdapat dalam LKS disebut sebagai pertanyaan inkuiri terbimbing (guided inquiry questions) 
yaitu seperangkat pertanyaan yang menuntut siswa untuk fokus pada kata kunci dalam materi pembelajaran. Pertanyaan ini membantu siswa mengumpulkan informasi dan membangun argumen berdasarkan bukti (Lee et al, 2006, p.157).

Salah satu model pembelajaran yang cocok untuk mempelajari fisika adalah model pembelajaran inkuiri terbimbing melalui metode eksperimen. Metode eksperimen ialah suatu cara penyajian mata pelajaran dimana siswa secara aktif mengalami dan membuktikan sendiri apa yang sedang dipelajarinya. Melalui metode ini siswa secara total dilibatkan dalam melakukan sendiri, membuktikan dan menarik kesimpulan sendiri tentang suatu objek, keadaan atau proses tertentu (Djamarah dan Zain, 2010, p.84). Metode eksperimen melatih siswa untuk merekam semua data fakta yang diperoleh melalui hasil pengamatan dan bukan data opini hasil rekayasa pemikiran. Sewaktu menyusun suatu kesimpulan, siswa didorong untuk menarik kesimpulan berdasarkan data hasil pengamatan menurut pandangan siswa, mereka perlu dilatih untuk tidak hanya asal menjawab, asal menyimpulkan, dan asal mencatat saja. Kumar et al (2009, p.5) menyatakan pembelajaran dengan metode eksperimen akan lebih efektif jika ada ruang dan waktu bagi guru dan siswa untuk merencanakan eksperimen, mendiskusikan ide-ide, kritis merekam dan menganalisa pengamatan. Metode eksperimen juga sering disebut sebagai percobaan yaitu cara penyajian pelajaran, dimana siswa melakukan percobaan dengan mengalami sendiri suatu yang dipelajari.

Berdasarkan uraian tersebut, maka dapat disimpulkan model pembelajaran inkuiri terbimbing melalui metode eksperimen yang digunakan dalam penelitian adalah model pembelajaran inkuiri terbimbing yang menggunakan metode eksperimen dalam pembelajaran yang dilakukan. Dalam pembelajaran guru menyajikan masalah yang berkaitan dengan pokok bahasan suhu dan kalor; guru membimbing siswa dalam mengumpulkan informasi tentang masalah yang disajikan; guru membimbing siswa dalam melakukan eksperimen yang berkaitan dengan pokok bahasan suhu dan kalor seperti dalam menyusun hipotesis, mendesain/melakukan eksperimen yaitu dalam menentukan variabel bebas, variabel terkontrol dan variabel terikat dari eksperimen yang berkaitan dengan pokok bahasan suhu dan kalor tersebut, melakukan pengukuran, dan menarik kesimpulan; guru membimbing siswa dalam merumuskan penjelasan dan membantu siswa dalam menganalisis pola-pola penemuan siswa yang berupa kesimpulan.

Model pembelajaran inkuiri terbimbing melalui metode eksperimen diharapkan dapat meningkatkan hasil belajar aspek kognitif dan keterampilan proses sains yang dimiliki oleh siswa. Menurut Bloom hasil belajar dalam ranah kognitif ada enam tingkatan yaitu mengenal, pemahaman, penerapan, analisis, sintesis dan evaluasi (Anderson dan Krathwohl, 2001, pp.6683). Hasil belajar merupakan hasil yang dicapai siswa setelah melakukan kegiatan belajar pada mata pelajaran fisika secara efektif di sekolah. Hasil belajar dapat berupa penguasaan materi dan simbol lain yang berkaitan dengan mata pelajaran fisika yang diberikan dalam bentuk tes tertulis atau penugasan lainnya oleh guru.

Untuk mengetahui tingkat pencapaian tujuan belajar fisika dilakukan pengukuran dengan cara evaluasi. Evaluasi merupakan pengungkapan dan pengukuran hasil belajar itu pada dasarnya adalah proses penyusunan deskripsi siswa baik secara kuantitatif maupun kualitatif. Akan tetapi kebanyakan pelaksanaan evaluasi cenderung bersifat kuantitatif. Hal ini dikarenakan menggunakan simbol dan angka atau skor untuk menentukan kualitas keseluruhan kinerja akademik siswa dianggap nisbi (Syah, 1995, p.142).

Dalam penelitian yang dilakukan, hasil belajar aspek kognitif yang dimaksud adalah tingkat pengenalan/ingatan, pemahaman, penerapan, analisis, sintesis dan evaluasi, namun tidak semua jenjang kognitif diteliti. Hasil belajar aspek kognitif yang diteliti hanya tingkat pengenalan yaitu dapat mengingat kembali konsep suhu dan kalor yang dimiliki siswa untuk menyelesaikan soal/masalah yang diberikan oleh guru, pemahaman yaitu dapat menghubungkan antara pengetahuan tentang suhu dan kalor yang dimiliki siswa dengan soal/masalah yang diberikan oleh guru dan penerapan yaitu dapat memilih suatu konsep yang berkaitan dengan pokok bahasan suhu dan kalor untuk diterapkan secara benar dalam soal/masalah yang diberikan oleh guru. Hasil belajar aspek kognitif diukur menggunakan soal pretest dan posttes. Jadi soal pretest dan posttest yang digunakan dikembangkan berdasarkan kisi-kisi hasil belajar aspek kognitif yang berkaitan dengan pokok bahasan suhu dan kalor dalam jenjang kognitif pengenalan, pemahaman dan penerapan.

Selain hasil belajar aspek kognitif, model pembelajaran inkuiri terbimbing melalui metode 
eksperimen juga diharapkan dapat meningkatkan keterampilan proses sains.

Mengembangkan keterampilan proses sangat penting untuk membangun pemahaman tentang dunia dan pembelajaran sains, misalnya: ide-ide dan konsep-konsep yang menjelaskan bagaimana alam dan buatan manusia bekerja (Rankin, 2006, p.19). Siswa dapat belajar sains dengan baik ketika metode pengajaran memungkinkan mereka untuk terlibat secara aktif dalam kegiatan kelas. Mereka harus berpartisipasi aktif dalam melakukan eksperimen, melakukan demonstrasi, diskusi kelas dan pengalaman belajar lain yang relevan (Chebii et al, 2012, p.1291).

Dalam penelitian ini, keterampilan proses sains yang dimaksud adalah kemampuan dalam kemampuan mengamati, menghitung, mengukur, mengklasifikasikan, menemukan hubungan, membuat prediksi, melakukan penelitian, mengumpulkan dan menganalisis data, menginterpretasikan data serta mengkomunikasikan hasil penelitian, namun tidak semua aspek keterampilan proses sains diobservasi. Keterampilan proses sains yang diteliti hanya kemampuan mengamati yaitu menggunakan semua indera yang sesuai untuk memperoleh informasi dari eksperimen yang dilakukan berkaitan dengan pokok bahasan suhu dan kalor; membuat prediksi yaitu dapat membuat hipotesis dari masalah yang berkaitan dengan pokok bahasan suhu dan kalor yang disajikan; melakukan penelitian/ eksperimen seperti melaksanakan eksperimen yang berkaitan dengan pokok bahasan suhu dan kalor sesuai dengan variabel bebas, variabel terkontrol dan variabel terikat yang telah ditentukan serta dapat menguji hipotesis yang telah dibuat, kemampuan mengukur yaitu dapat membandingkan hasil pengukuran dengan unit standar pengukuran yang telah ada, dan kemampuan menyimpulkan yaitu dapat menyimpulkan/memutuskan hasil yang diperoleh dari eksperimen sesuai dengan pokok bahasan suhu dan kalor yang dipelajari. Keterampilan proses sains diukur dengan menggunakan lembar observasi keterampilan proses sains. Lembar observasi keterampilan proses sains dikembangkan berdasarkan kisi-kisi lembar observasi keterampilan proses sains sesuai dengan indikator kemampuan mengamati, membuat prediksi, melakukan eksperimen, mengukur dan menyimpulkan.

\section{METODE}

Penelitian ini menggunakan model penelitian quasi eksperimen. Penelitian dilakukan pada dua kelas yaitu kelas eksperimen dan kelas kontrol. Kelas eksperimen merupakan kelas yang menggunakan model pembelajaran inkuiri terbimbing melalui metode eksperimen dalam pembelajaran fisika sedangkan kelas kontrol merupakan kelas yang menggunakan model pembelajaran konvensional melalui metode ceramah. Pretest dan posttest dalam penelitian ini digunakan untuk mengukur kemampuan awal fisika dan kemampuan akhir fisika siswa. Keterampilan proses sains diukur dengan menggunakan lembar observasi.

Penelitian ini dilaksanakan pada bulan Maret sampai Mei tahun 2015 di SMA Negeri 9 Yogyakarta. Populasi dalam penelitian ini adalah seluruh siswa kelas X SMA Negeri 9 Yogyakarta semester genap tahun ajaran 2014/2015 sebanyak 192 siswa. Teknik pengambilan sampel dilakukan secara cluster randomized sampling yaitu sampel dipilih secara acak karena populasi berasal dari varians yang homogen. Homogen diartikan siswa memiliki kemiripan pengetahuan awal fisika. Sampel yang terpilih adalah siswa kelas X5 dan X6. Adapun dalam menentukan kelas eksperimen dan kelas kontrol menggunakan sistem acak atau random. Dari hasil sistem acak tersebut diperoleh 32 siswa kelas X5 sebagai kelas eksperimen yang menggunakan model pembelajaran inkuiri terbimbing melalui metode eksperimen dan 32 siswa kelas X6 sebagai kelas kontrol yang menggunakan model pembelajaran konvesional melalui metode ceramah.

Variabel bebas dalam penelitian ini adalah model pembelajaran inkuiri terbimbing melalui metode eksperimen dan model pembelajaran konvesional melalui metode ceramah. Variabel terikat pada penelitian ini adalah hasil belajar aspek kognitif dan keterampilan proses sains. Variabel terkontrol dalam penelitian ini adalah materi pembelajaran, guru yang mengajar dan lama waktu pembelajaran yang sama antara kelas eksperimen dan kelas kontrol.

Desain penelitian yang digunakan dalam penelitian ini adalah

\begin{tabular}{lccc}
\hline Kelompok & Pretest & $\begin{array}{c}\text { Perlakuan } \\
\text { (variabel } \\
\text { bebas) }\end{array}$ & $\begin{array}{c}\text { Posttest } \\
\text { (variabel } \\
\text { terikat) }\end{array}$ \\
\hline Eksperimen & $Y_{1}$ & $X_{\text {eksperimen }}$ & $Y_{2}$ \\
Kontrol & $Y_{1}$ & $X_{\text {ceramah }}$ & $Y_{2}$ \\
\hline
\end{tabular}

\section{Keterangan:}

$X_{\text {eksperimen }}=$ pembelajaran fisika dengan menggunakan model pembelajaran inkuiri terbimbing melalui metode eksperimen

$X_{\text {ceramah }}=$ pembelajaran fisika dengan menggunakan model inkuiri terbimbing melalui metode ceramah $Y_{I}=$ tes kemampuan awal fisika 
$Y_{2}=$ tes kemampuan akhir fisika

Data yang diperoleh dalam penelitian ini adalah data hasil belajar aspek kognitif dan hasil observasi keterampilan proses sains. Instrumen dalam penelitian ini adalah tes hasil belajar aspek kognitif siswa berupa soal pretest-posttest dan lembar observasi keterampilan proses sains. Teknik pengumpulan data yang digunakan pada penelitian ini menggunakan tes dan non tes. Teknik tes digunakan untuk mengukur hasil belajar aspek kognitif siswa. Tes hasil belajar aspek kognitif berupa soal uraian sebanyak sembilan butir soal. Peningkatan hasil belajar aspek kognitif dapat dilihat dan diukur dengan soal pretest dan posttest yang sama. Teknik nontes digunakan untuk mengetahui hasil observasi keterampilan proses sains siswa selama pembelajaran fisika. Observasi dilakukan sebanyak enam kali, baik pada kelas eksperimen maupun kelas kontrol Data keterampilan proses sains diperoleh dari hasil observasi dengan lima aspek, yaitu: pengamatan, pelaksanaan penelitian, pengkomunikasian, peramalan, dan penyimpulan. Sebelum diberikan perlakuan, dilakukan pretest pada kelas eksperimen dan kelas kontrol untuk mengetahui kemampuan awal fisika siswa.

Data hasil penelitian dianalisis secara statistik menggunakan multiple analysis of covariance (MANCOVA) yang dilakukan dengan bantuan software SPSS 16. Pada uji hipotesis, taraf signifikansi yang digunakan adalah 5\% atau 0,05. Keputusan uji hipotesis ditentukan dengan kriteria: jika $\mathrm{p}<0,05$ maka hipotesis nol $\left(\mathrm{H}_{0}\right)$ ditolak yang berarti ada peningkatan hasil belajar aspek kognitif dan keterampilan proses sains ditinjau dari kemampuan awal fisika apabila dilakukan pembelajaran dengan model pembelajaran inkuiri terbimbing melalui metode eksperimen.

\section{HASIL DAN PEMBAHASAN}

\section{Deskripsi Data Penelitian}

Keterampilan Proses Sains

Data keterampilan proses sains diperoleh dari hasil observasi dengan lima aspek keterampilan proses sains yaitu: pengamatan, pelaksanaan penelitian, pengkomunikasian, peramalan, dan penyimpulan. Observasi dilakukan sebanyak enam kali, baik pada kelompok eksperimen maupun kelompok kontrol, keduanya dilakukan observasi terhadap masing-masing siswa.
Distribusi frekuensi keterampilan proses sains untuk kelas eksperimen berdasarkan pengkategorian nilai dapat dilihat pada Tabel 1.

Tabel 1. Distribusi Frekuensi Keterampilan Proses Sains Kelas Eksperimen

\begin{tabular}{clcrc}
\hline \multirow{2}{*}{ No. Kategori Jawaban } & \multirow{2}{*}{ Norma } & \multicolumn{2}{c}{ Frekuensi } \\
\cline { 3 - 5 } & & & F & \% \\
\hline 1. & Sangat Baik & $81-100$ & 14 & 43,8 \\
2. & Baik & $66-80$ & 16 & 50,0 \\
3. & Cukup & $51-65$ & 2 & 6,2 \\
4. & Kurang & $\leq 50$ & 0 & 0,0 \\
\hline \multicolumn{2}{r}{ Jumlah } & & 32 & 100,0 \\
\hline
\end{tabular}

Distribusi frekuensi keterampilan proses sains untuk kelas eksperimen berdasarkan pengkategorian nilai dapat dilihat pada Tabel 2.

Tabel 2. Distribusi Frekuensi Keterampilan Proses Sains Kelas Kontrol

\begin{tabular}{clccc}
\hline \multirow{2}{*}{ No. } & \multirow{2}{*}{ Kategori Jawaban } & \multirow{2}{*}{ Norma } & \multicolumn{2}{c}{ Frekuensi } \\
\cline { 4 - 5 } & & & F & \% \\
\hline 1. & Sangat Baik & $81-100$ & 0 & 0,0 \\
2. & Baik & $66-80$ & 0 & 0,0 \\
3. & Cukup & $51-65$ & 17 & 53,1 \\
4. & Kurang & $\leq 50$ & 15 & 46,9 \\
& & & 32 & 100,0 \\
\hline
\end{tabular}

Berdasarkan Tabel 1 dan 2 dapat disimpulkan bahwa keterampilan proses sains pada kelas eksperimen berada pada kategori baik sedangkan pada kelas kontrol pada kategori cukup baik.

\section{Kemampuan Awal Fisika}

Data kemampuan awal fisika diambil dengan teknik tes yang berbentuk uraian dengan sembilan soal. Data selanjutnya dikonversi ke dalam nilai dengan skala 100 , sehingga diperoleh rentangan nilai antara 0 sampai dengan 100. Distribusi frekuensi kemampuan awal fisika untuk kelas eksperimen berdasarkan pengkategorian nilai pada Tabel 3.

Tabel 3. Distribusi Frekuensi Kemampuan Awal Fisika Kelas Eksperimen

\begin{tabular}{clccc}
\hline \multirow{2}{*}{ No. } & \multirow{2}{*}{ Kategori Jawaban } & \multirow{2}{*}{ Norma } & \multicolumn{2}{c}{ Frekuensi } \\
\cline { 3 - 5 } & & $81-100$ & 0 & 0,0 \\
\hline 1. & Sangat Baik & $66-80$ & 0 & 0,0 \\
2. & Baik & $51-65$ & 0 & 0,0 \\
3. & Cukup & $\leq 50$ & 32 & 100,0 \\
4. & Kurang & & 32 & 100,0 \\
\hline
\end{tabular}

Distribusi frekuensi kemampuan awal fisika untuk kelas kontrol berdasarkan pengkategorian nilai pada Tabel 4. 
Tabel 4. Distribusi Frekuensi Kemampuan Awal Fisika Kelas Kontrol

\begin{tabular}{clccc}
\hline \multirow{2}{*}{ No. Kategori Jawaban } & \multirow{2}{*}{ Norma } & \multicolumn{2}{c}{ Frekuensi } \\
\cline { 3 - 5 } & & & f & \% \\
\hline 1. & Sangat Baik & $81-100$ & 0 & 0,0 \\
2. & Baik & $66-80$ & 0 & 0,0 \\
3. & Cukup & $51-65$ & 0 & 0,0 \\
4. & Kurang & $\leq 50$ & 32 & 100,0 \\
\hline \multicolumn{2}{r}{ Jumlah } & & 32 & 100,0 \\
\hline
\end{tabular}

Berdasarkan data pada Tabel 3 dan 4 dapat disimpulkan bahwa kemampuan awal fisika pada kelas eksperimen dan kontrol berada pada kategori kurang baik.

Kemampuan Akhir Fisika

Seperti halnya pada data kemampuan awal fisika, data kemampuan akhir fisika diambil dengan tes yang sama, yang berbentuk uraian dengan 9 soal, dengan skala nilai antara 0 sampai dengan 100. Distribusi frekuensi kemampuan akhir fisika untuk kelas eksperimen berdasarkan pengaktegorian nilai pada Tabel 5 .

Tabel 5. Distribusi Frekuensi Kemampuan Akhir Fisika untuk Kelas Eksperimen

\begin{tabular}{clcrr}
\hline \multirow{2}{*}{ No. Kategori Jawaban } & \multirow{2}{*}{ Norma } & \multicolumn{2}{c}{ Frekuensi } \\
\cline { 3 - 5 } & & & F & \% \\
\hline 1. & Sangat Baik & $81-100$ & 12 & 37,5 \\
2. & Baik & $66-80$ & 11 & 34,4 \\
3. & Cukup & $51-65$ & 8 & 25,0 \\
4. & Kurang & $\leq 50$ & 1 & 3,1 \\
\hline \multicolumn{2}{r}{ Jumlah } & & 32 & 100,0 \\
\hline
\end{tabular}

Distribusi frekuensi kemampuan akhir fisika untuk kelas kontrol berdasarkan pengaktegorian nilai pada Tabel 6 .

Tabel 6. Distribusi Frekuensi Kemampuan Akhir Fisika untuk Kelas Kontrol

\begin{tabular}{cccrc}
\hline \multirow{2}{*}{ No } & \multirow{2}{*}{ Kategori Jawaban } & \multirow{2}{*}{ Norma } & \multicolumn{2}{c}{ Frekuensi } \\
\cline { 3 - 5 } & & F & \multicolumn{1}{c}{$\%$} \\
\hline 1. & Sangat Baik & $81-100$ & 0 & 0,0 \\
2. & Baik & $66-80$ & 9 & 28,1 \\
3. & Cukup & $51-65$ & 14 & 43,8 \\
4. & Kurang & $\leq 50$ & 9 & 28,1 \\
\hline & Jumlah & & 32 & 100,0 \\
\hline
\end{tabular}

Berdasarkan data pada Tabel 5 dan 6 dapat disimpulkan bahwa kemampuan akhir fisika pada kelas eksperimen berada pada kategori sangat baik sedangkan pada kelas kontrol berada kategori cukup baik.

\section{Penguasaan Konsep Siswa}

Untuk mendapatkan gambaran sejauh mana penguasaan konsep siswa setelah mengikuti pembelajaran dapat dilihat dari peningkatan perolehan rata-rata skor pretest terhadap skor posttest atau nilai normalisasi gain ( $N$-gain). Perolehan nilai rata-rata pretest dan posttest serta besar $\mathrm{N}$-Gain untuk kelas eksperimen dan kelas kontrol pada tabel 7.

Tabel 7. Nilai Rata-rata Pretest dan Posttest serta $N$-Gain Kelas Eksperimen dan Kontrol

\begin{tabular}{cccc}
\hline Kelas & $\begin{array}{c}\text { Rata-rata } \\
\text { Nilai } \\
\text { Pretest }\end{array}$ & $\begin{array}{c}\text { Rata-rata } \\
\text { Nilai } \\
\text { Posttest }\end{array}$ & $\begin{array}{c}\text { N- } \\
\text { Gain }\end{array}$ \\
\hline Eksperimen & 22,19 & 74,44 & 0,68 \\
Kontrol & 22,16 & 56,78 & 0,45 \\
\hline
\end{tabular}

Perbandingan nilai rata-rata pretest untuk kelas eksperimen dan kelas kontrol dapat dilihat pada Gambar 1.

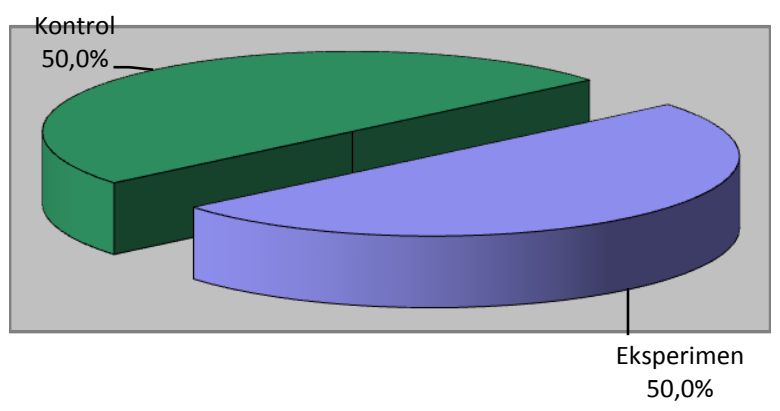

Gambar 1. Perbandingan Nilai Rata-rata Pretest Kelas Eksperimen dan Kontrol

Perbandingan nilai rata-rata posttest untuk kelas eksperimen dan kontrol dapat dilihat pada Gambar 2.

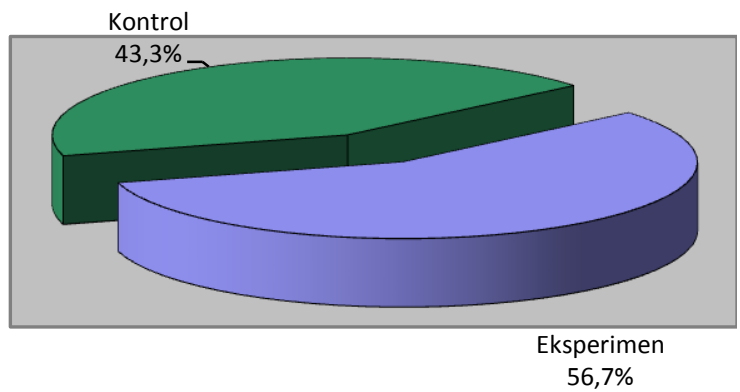

Gambar 2. Perbandingan Nilai Rata-rata Posttest Kelas Eksperimen dan Kontrol

Dari Gambar 1 dapat dilihat bahwa perbandingan nilai rata-rata pretest untuk kelas eksperimen dan kelas kontrol adalah sama besar yaitu $50 \%$. Namun rata-rata nilai posttest yang dihasilkan oleh kelas eksperimen lebih tinggi dibandingkan kelas kontrol, seperti yang ditunjukkan pada Gambar 2. Presentase nilai rata-rata posttest untuk kelas eksperimen adalah 56,7\% sedangkan untuk kelas kontrol adalah 43,3\%. 
Secara umum siswa mengalami peningkatan penguasaan konsep setelah mengikuti pembelajaran. Besar peningkatan penguasaan konsep ini dapat dilihat dari nilai normalisasi gain $(N$-gain) yang diperoleh. $(N$-gain $)$ merupakan peningkatan hasil belajar siswa yang diperoleh skor ideal dari skor posttest dikurangi skor pretest dibagi skor maksimum dikurangi skor pretest. Tingkat perolehan gain ternormalisasi dari kedua kelas dikategorikan dalam kategori sedang. Dari tabel dapat dilihat nilai $\mathrm{N}$ gain untuk kelas eksperimen sebesar 0,68 dan untuk kelas kontrol sebesar 0,45. Jadi dapat disimpulkan peningkatan penguasaan konsep untuk kelas eksperimen lebih besar daripada peningkatan penguasaan konsep kelas kontrol.

\section{Hasil Multiple Analysis of Covariance (MANCOVA) dalam Penelitian}

Berdasarkan uji statistik (MANCOVA) yang dilakukan dapat dideskripsikan bahwa terdapat perbedaan yang signifikan kemampuan akhir fisika antara kelompok eksperimen dengan kelompok kontrol setelah diberi perlakuan berupa pembelajaran dengan model pembelajaran inkuiri terbimbing melalui metode eksperimen ditinjau dari kemampuan awal fisika, yang dibuktikan dengan $\mathrm{F}=47,539$ dengan $\mathrm{p}=0,000$; terbukti $\mathrm{p}<0,05$. Terdapat juga perbedaan yang signifikan keterampilan proses sains antara kelompok eksperimen dengan kelompok kontrol setelah diberi perlakuan berupa pembelajaran dengan model pembelajaran inkuiri terbimbing melalui metode eksperimen ditinjau dari kemampuan awal fisika, yang dibuktikan dengan $\mathrm{F}=189,135$ dengan $\mathrm{p}=0,000$; terbukti $\mathrm{p}<0,05$. Kemampuan awal fisika dalam penelitian berla$\mathrm{ku}$ sebagai variabel kovarian, terbukti mendukung peningkatan kemampuan fisika, yang dibuktikan dengan $\mathrm{F}=58,702$ dan $\mathrm{p}=0,000$ $(\mathrm{p}<0,05)$. Kemampuan awal fisika juga terbukti mendukung peningkatan keterampilan proses sains, yang dibuktikan dengan $\mathrm{F}=18,230$ dan $\mathrm{p}=0,000(\mathrm{p}<0,05)$.

Dari hasil analisis tersebut, terbukti bahwa terdapat pengaruh positif yang signifikan model pembelajaran inkuiri terbimbing melalui metode eksperimen terhadap peningkatan hasil belajar fisika aspek kognitif dan keterampilan proses sains ditinjau dari kemampuan awal fisika pada siswa kelas X di SMA Negeri 9 Yogyakarta. Hasil ini membuktikan bahwa hipotesis nihil (Ho) yang menyatakan: "Tidak terdapat peningkatan hasil belajar fisika aspek kognitif dan keterampilan proses sains ditinjau dari kemampuan awal fisika pada siswa kelas $\mathrm{X}$ di SMA Negeri 9 Yogyakarta dengan model pembelajaran inkuiri terbimbing melalui metode eksperimen" ditolak, dan hipotesis asli/alternatif (Ha) yang menyatakan "Terdapat peningkatan hasil belajar fisika aspek kognitif dan keterampilan proses sains ditinjau dari kemampuan awal fisika pada siswa kelas $X$ di SMA Negeri 9 Yogyakarta dengan model pembelajaran inkuiri terbimbing melalui metode eksperimen" diterima.

\section{SIMPULAN}

Berdasarkan hasil analisis data dan pembahasan, dapat diambil kesimpulan yaitu terdapat peningkatan yang signifikan hasil belajar fisika aspek kognitif dan keterampilan proses sains ditinjau dari kemampuan awal fisika pada siswa kelas X di SMA Negeri 9 Yogyakarta dengan model pembelajaran inkuiri terbimbing melalui metode eksperimen.

Pembelajaran dengan model pembelajaran inkuiri terbimbing melalui metode eksperimen sebaiknya diterapkan di sekolah untuk mendukung peningkatan hasil belajar aspek kognitif dan keterampilan proses sains pada siswa dalam mempelajari materi pelajaran fisika khususnya pada pokok bahasan suhu dan kalor.

\section{DAFTAR PUSTAKA}

Alberta Education. (2004). Focus on inquiry. Canada: Alberta Education.

Anderson, L. W., \& Krathwohl, D. R. (2001). A taxonomy for learning, teaching and assessing. New York: Addison Wesley Longman, Inc.

Asminah, D. R. (2010). Pembelajaran fisika dengan metode inkuiri terbimbing dan inkuiri training ditinjau dari kemampuan awal dan aktifitas siswa. Tesis, tidak dipublikasikan. Universitas Sebelas Maret Surakarta.

Bloom, B. S., Engelhart, M. D., \& Furst, E. J., et al. (1956). Taxonomy of educational objectives. New York: David McKay Company, Inc.

Bransford, J. D., Brown, A. L., \& Cocking, R. R. (1999). How people learn: brain, mind, experience and school. Washington D.C: National Academy Press.

Chebii, R., Wachanga, S., \& Kiboss, J. (2012). Effects of science process skills mastery learning approach on students' acquisition of selected chemistry practical skills in 
school. Creative Education, 3(1), 12911296.

Dimyati \& Mudjiono. (1999). Belajar dan pembelajaran. Jakarta: Rineka Cipta.

Djamarah, S. B., \& Zain, A. (2010). Strategi belajar mengajar. Jakarta: Rineka Cipta.

Jack, G. U. (2013). Concept mapping and guided inquiry as effective techniques for teaching difficult concepts in chemistry: effect on students' academic achievement. Journal of Education and Practice, 4(1), 9-15.

Joyce \& Weil. (2003). Model of teaching ( $3^{\text {rd }}$ ed). New Delhi: Prentice Hall of India Private Limited.

Kuhlthau,C. C., Maniotes, L. K., \& Caspari, A. K. (2007). Guided inquiry: Learning in the 21st century school. USA: Libraries Unlimited, Inc.

Kumar, A., Singh, S., \& Chakrabarty, J., et al. (2006). Teaching of science. New Delhi: National Council of Educational Research and Training.

Lee, W. J., Puspitasari, K. A., \& Kim, H. Y., et al. (2006). The effects of guided inquiry questions on students' critical thinking skills and satisfaction in online argumentation. Journal of Florida, 1(1), 156-162.

Mariana, I. M. A., \& Praginda, W. (2009). Hakikat IPA dan pendidikan IPA. Bandung: PPPPTK IPA.

Martin, M. O., Mullis, I. V. S., \& Foy, P. (2008). TIMSS 2007 international science report findings from IEA's trends in international mathematics and science study at the fourth and eighth grades. Boston: International Association for the Evaluation of Educational Achievement (IEA).

McBride, J. W., Bhatty, M. I., \& Hannan, M. A., et al. (2004). Using an inquiry approach to teach science to secondary school science teachers. Journal Physics Education, 5(2), 1-6.
Mulyasa, E. (2011). Menjadi guru professional: menciptakan pembelajaran yang kreaktif dan menyenangkan. Bandung: PT Remaja Rosda Karya.

Ozdilek, Z., \& Bulunuz, N. (2009). The effect of a guided inquiry method on pre-service teachers' science teaching self-efficacy beliefs. Journal of Turkish Science Education, 6(1), 24-42.

Prakosa, Ibnu. (2011). Pembelajaran inkuiri terbimbing menggunakan metode demonstrasi dan metode eksperimen ditinjau dari keingintahuan dan perhatian siswa. Tesis, tidak dipublikasikan. Universitas Sebelas Maret Surakarta.

Rankin, L. (2006). Assessing process skills: A professional development curriculum from the institute for inquiry. San Francisco: Exploraturium.

Republik Indonesia. (2003). Undang-Undang RI nomor 20, tahun 2003, tentang standar nasional pendidikan.

Suparno, P. (2007). Metodologi pembelajaran fisika. Yogyakarta: Universitas Sanata Dharma

Syah, M. (1995). Psikologi pendidikan dengan pendekatan baru. Bandung: PT. Remaja Rasdakarya.

Tavalin, F. (2002). A Guide to inquiry-based study groups. USA: United States Department of Education.

Vlassi, M., \& Karaliota, A. (2013). The comparison between guided inquiry and traditional teaching method. A case study for the teaching of the structure of matter to 8th grade Greek students. Procedia Social and Behavioral Sciences, Greece, 93(4), 494-497.

Villagonzalo, E. C. (2014). Process oriented guided inquiry learning: an effective approach in enhancing students' academic performance. DLSU Research Congress ,2 (1), 1-6. 